\title{
Research and Implementation of B2B E-commerce System
}

\author{
Qi Ligen \\ Jiangxi College Of Foreign Studies
}

\begin{abstract}
Informatization accelerates economic globalization and makes profound changes in the way human produce and live. In the tide of economic globalization and informatization, with its advantages of high efficiency, fast and convenience, E-commerce has become a major application field of economic globalization and global informatization because of the brand-new management idea, management means and management environment. E-commerce is no longer the development goal of one enterprise or industry in this era, but a topic facing all the world. It has gradually become the evaluation of a country' s economic strength and an important index to measure a country' $s$ international status. This paper first elaborates E-commerce from the definition, mode, characteristics of E-commerce and its influence to social economy and then have a comprehensive and systematic study of the knowledge and technology required to construct E-commerce. It introduces the developing environment, structure design and business process of B2B E-commerce system from analyzing E-commerce system.
\end{abstract}

Keyword-E-commerce; B2B; Platform; Structure; Business process

\section{INTRODUCTION}

At the end of the 20th century, under the impetus of the globalization and informatization, the most charming slogan is "E-commerce" . E-commerce can unit people' $s$ thought and action in the shortest time and it is a innovation in global economy field. E-commerce means the main body of economic activity is no longer be confined to the developed countries but people all over the world. E-commerce is the embodiment and integration of globalization and informatization and the inevitable result of the globalization and informatization development. It' s changing the social economic life and the whole world. E-commerce in our country has made great progress after several years' development and penetrated into all aspects of social economy. Application of leading, market-orientation, resource sharing, technology innovation, competition and development have become the guideline to develop E-commerce in our country.

E-commerce system must be able to accurately reflect the real world of business activities, achieve all kinds of business process between enterprises and provide a feasible method marketing means and marketing method on international internet to enterprises marketing management to solve the problems of slow goods information flow, inaccurate information and small circulation surface. B2B E-commerce system aims at providing an brief, reasonable, convenient, just, fair and open trade method, properly solving the existing problems of enterprise fund, management condition unclear and affecting management decisions .Enterprise internal management of B2B E-commerce system requires to divide the authorities of the internal business personnel (mainly system officer, salesperson, buyer and finance personnel)clearly, and no unauthorized operation. Besides, B2B E-commerce system should also have the functions of auction, bidding and intelligence search engine. B2B E-commerce platform can not only promote business process automation, reduce production cost, improve enterprise overall efficiency and guarantee the safety and reliability of E-commerce.

This paper gives a detailed introduction of the design process of B2B E-commerce system and the establishment of PHP + My SQL development environment and explain in detail each module in the system and gives some examples. Besides, it also briefly introduces some information system related to E-commerce system.

\section{INTRODUCTION OF E-COMMERCE}

E-commerce refers to achieve the entire business from pre-sales to after-sales or the electronic and automation of trading activity segment. For enterprises, E-commerce is to make use of information technology with the core of internet to carry on business activity and enterprise resource management. It' $s$ core is to efficiently manage all the enterprise information ,help enterprise to create an smooth information flow between customers, enterprise internal and suppliers and connect customers, enterprises and suppliers with high efficiency management, value added and application, respond market with the quickest speed and lowest cost, timely grasp the business opportunity and constantly improve and consolidate the competitive advantages.

E-commerce can be divided into four categories: First, products operating activities through network implementation between enterprises and enterprises. Second, service operating activities through network implementation between enterprises and enterprises. Third, products operating activities through network between enterprises and individuals. Fourth, service operating activities through network between enterprises and individuals.

The goal of E-commerce:

1.Amplify consumers, deepen the contact between the users and expand market to increase income.

2.Reduce cost

3.Reduce products circulation time

4.Speed up the responding speed to consumer requirements

5.Improve service quality 
E-commerce has the following characteristics: structural, interactivity, real-time, global, low cost and competitive.

\section{B2B E-COMMERCE SYSTEM DESIGN ANALYSIS}

In order to set up a reasonable, convenient and safe B2B E-commerce system, first it should have the management work of background manager; second, the trading modules divided according to business processing flow of the members should be reasonable and user-friendly; third, in B2B E-commerce system, since members represent for companies, the business salesman

(buyer, sales, finance, etc.) within membership should perform their duties and no unauthorized operation allowed.

B2B E-commerce system includes foreground and background. Foreground mainly provide operation for members, including browsing, query and information statistics and so on; Background mainly provides maintenance and supervision site operation for supervisor and management committee.

The life cycle of E-commerce application system refers to a life cycle from the establishing to abandoning E-commerce system .It can be divided into 6 stages: E-commerce application system feasibility analysis, system plan, system analysis, system design, system achievement and system operation management. As shown in Fig.1.

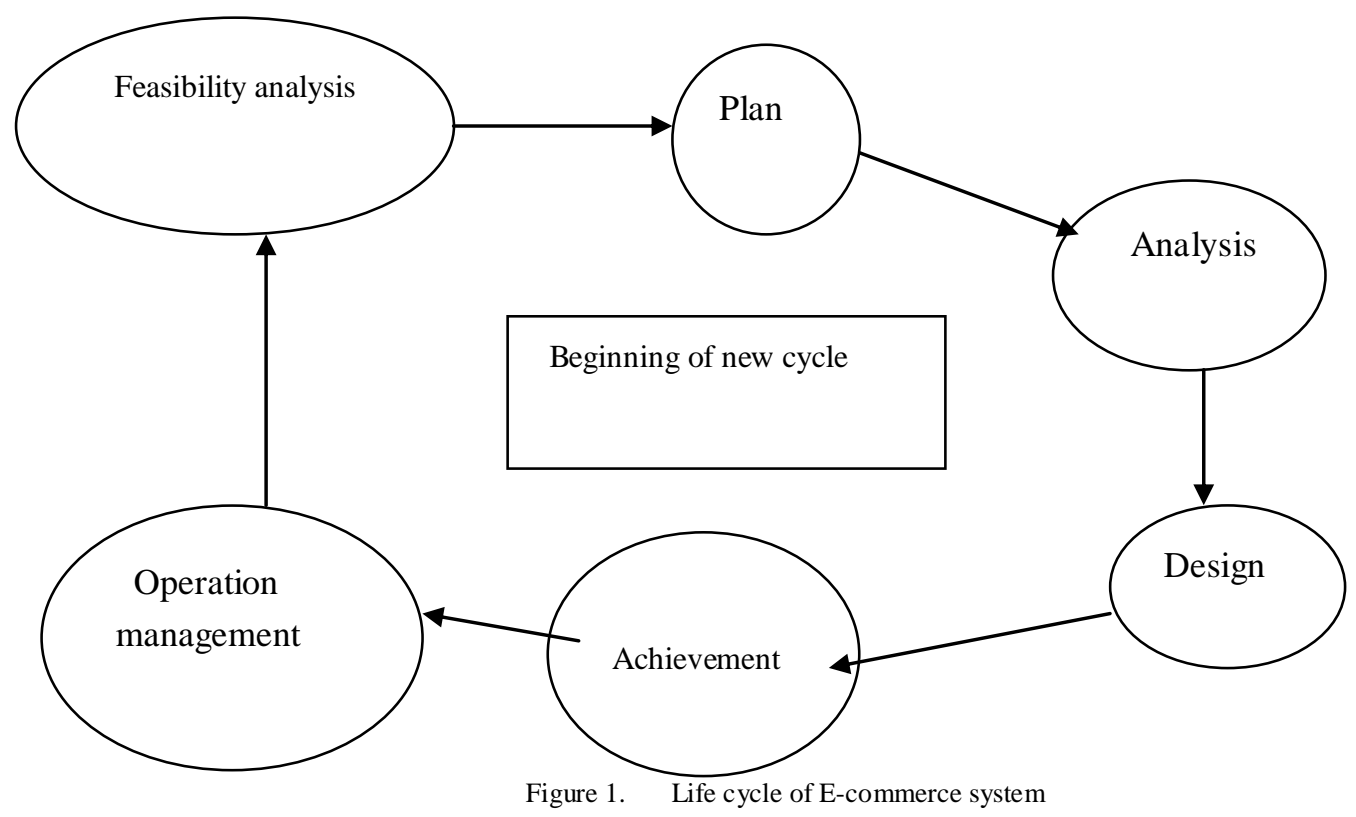

The development of E-commerce application system is the first 5 stages.

\section{DESIGN OF B2B E-COMMERCE SYSTEM}

There is no authoritative discussion about what a perfect E-commerce system should include. Overall, E-commerce system is a three-layer frame structure. The first layer is network platform, which is the carrier of information transmission and the means of user intervention. It includes various physical transfer platform and transfer way. The middle layer is E-commerce basic platform, including certificate authority (CA), payment Gateway and customer service center. The real core is CA. The third layer is various E-commerce application system, including E-commerce, remote medicine, stock trading and video on demand. E-commerce safety system is in charge of the information security in the process of business transaction. E-commerce foundation platform is the foundation of all kinds of E-commerce application system. As shown in Fig .2. 


\begin{tabular}{|c|c|c|c|c|c|c|c|c|c|c|c|c|}
\hline 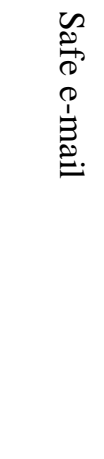 & 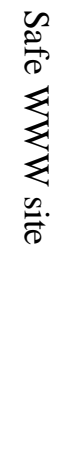 & 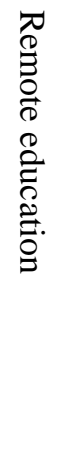 & 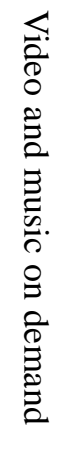 & 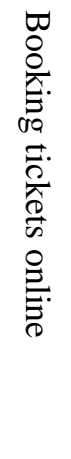 & 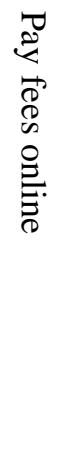 & 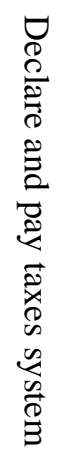 & 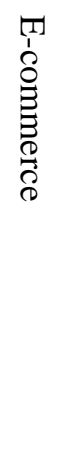 & 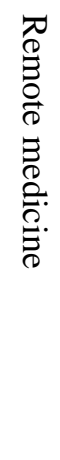 & 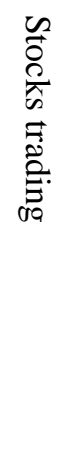 & $\begin{array}{l}Z \\
Z \\
\substack{0 \\
\infty}\end{array}$ & 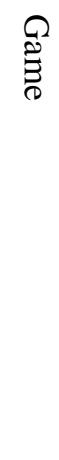 & 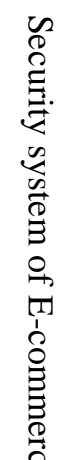 \\
\hline \multicolumn{12}{|c|}{ CA center, payment gateway and customer service center } & \\
\hline \multicolumn{12}{|c|}{ Chinese public multimedia data network } & \\
\hline
\end{tabular}

Figure 2. Three-tier structure of E-commerce

The specific function service description of E-commerce basic platform

\section{A. Authentication}

Since E-commerce is to carry on business activities via internet in means of electronic. Usually all the parties involved don' t see each other, so identity confirmation and security communication become very important.

\section{B. Payment gateway}

Payment gateway is the mediation between information network and financial network. It takes the job of payment information transformation of both sides and the key problems it solved is to make traditional closed financial networks through gateway facing internet users and provide safe and convenient online payment function.

\section{CONCLUSION}

These companies are creating value when implementing E-commerce, but the value is not a simple thing. It' $s$ not achieved just by creating a website or a single dispersed online application. It comes from E-commerce idea and actual direction which has the original solution can be expanded into other higher business value field. E-commerce is not only the electronic trading business, with the help of technology it will redefine the old business model.

To sum up, B2B E-commerce is a mechanism, which can directly connect key business system to their users, employees, partners and suppliers through internal network, external network and wide area network. When users, employees, suppliers and distributors are connected to business system and obtain the required information , E-commerce is in fact innovated and integrated to key business process.

\section{REFERENCES}

[1] Kalakota, Ravi, and A. B. Whinston. "Frontiers of electronic commerce." Frontiers of Electronic Commerce (1996).

[2] Pavlou, Paul A. "Consumer Acceptance of Electronic Commerce: Integrating Trust and Risk with the Technology Acceptance Model." International Journal of Electronic Commerce 7.3(2003):101-134.

[3] Kini, Anil. "Trust in electronic commerce: definition and theoretical considerations." System Sciences, 1998., Proceedings of the Thirty-First Hawaii International Conference on IEEE, 1998:51-61 vol.4.

[4] Zwass, Vladimir. "Electronic commerce: structures and issues." International Journal of Electronic Commerce 1.1(1996):3-23.

[5] Pavlou, Paul A., and M. Fygenson. "Understanding and Predicting Electronic Commerce Adoption: An Extension of the Theory of Planned Behavior." Social Science Electronic Publishing 30.1(2006): 115-143.

[6] Metzger, and J. Miriam. "Privacy, Trust, and Disclosure: Exploring Barriers to Electronic Commerce .." Journal of Computer-Mediated Communication 9.4(2004):00-00.

[7] Chircu, Alina M., and R. J. Kauffman. "Reintermediation strategies in business-to-business electronic commerce." International Journal of Electronic Commerce 4.4(2000):7-42.

[8] Riggins, Frederick J., and H. S. Rhee. "Toward a Unified View of Electronic Commerce." Communications of the Acm 41.10(1998):88-95

[9] Kailar, R. "Accountability in Electronic Commerce Protocols." IEEE Transactions on Software Engineering 22.5(1996):313-328.

[10] Lynda M. Applegate, Clyde W. Holsapple, Ravi Kalakota, et al. Electronic commerce: Building blocks of new business opportunity $[\mathrm{J}]$. Journal of Organizational Computing \& Electronic Commerce, 1996, 6(1):1-10.

[11] Belanger F, Hiller J S, Smith W J. Trustworthiness in electronic commerce: the role of privacy, security, and site attributes. The Journal of Strategic Information Systems 11(3-4):245-270[J] Journal of Strategic Information Systems, 2002, 11(02):245-270.

[12] He, Minghua, N. R. Jennings, and H. F. Leung. "On Agent-Mediated Electronic Commerce." IEEE Transactions on Knowledge \& Data Engineering 15.4(2003):985-1003. 